DOI 10.38129/ Ann.Yur.Ist.2020.4.1.45

УДК 616-036.15:616-036.887(616-002.828: 616-036.17)

\title{
ХВОРОБА І СМЕРТЬ ПРАВИТЕЛЯ ДЕРЖАВИ: ВИПАДОК ГЕНРІ V ЛАНКАСТЕРА
}

\author{
ДМИТРО КОПИЛОВ (Львів, Україна)*
}

Quem di diligunt, adolescens moritur ${ }^{1}$. Цей афоризм можна вжити відносно короля Генрі V Ланкастера (1386-1422) який помер в віці 35 років. До сьогодні встановити точний діагно3, що призвів до смерті, не є можливим насамперед через те, що тіло короля при транспортуванні 3 Франції до Англії було розділено на частини і виварено в окропі. Варто наголосити, що більшість західноєвропейських істориків схильна вважати: причиною смерті була дизентерія, яка супроводжувала англійську армію із самого початку військової кампанії у Франції влітку 1415 р.

В історичній науці Великої Британії, не кажучи про Україну, практично не існує досліджень присвячених вказаній темі, однак вона стала предметом полеміки у вузькому колі спеціалістів Англії. Проте навіть тут ця тема швидше розглядалася через призму політичних перипетій у відносинах Королівств Англії і Франції, аніж 3 точки зору медицини. 3 огляду на це, тематика хвороби і смерті одного з найвідоміших англійських монархів досі залишається білою плямою в історії.

Встановити сьогодні точний діагноз недугу короля, який був таємничим ще для сучасників Генрі, з абсолютною точністю неможливо, однак джерельні повідомлення очевидців епохи, що описали симптоми цієї хвороби, можуть розкрити маловідомі факти смерті Генрі V і пролити світло на особливості медицини пізнього Середньовіччя.

По смерті свого батька, короля Генрі IV Ланкастера (1366-1413 ) в 1413 році, який також помер від точно не встановленої хвороби (висловлювалися думки, що це була лепра, «вогонь Святого Антонія» і навіть сифіліс) права на трон Англії перейшли його сину Генрі V².

1 Лат. Улюбленці богів помирають молодими. Цитата римського комедіографа Тіта Макція Плавта (254-184 рр. до н. е.), позичена ним у давньогрецького комедіографа Менандра (342-291 рр. до н. е.)

2 Бэррэтт Д. Война за английский престол. Битва при Шрусбери (1403 г.) / Джон Бэррэтт. - Санкт Петербург: Евразия, 2014. - С. 169 
В 1415 році 29-річний король, якого підтримали англійські богослови і юристи, заявляє своє право на французъку корону і оголошує їй війну. Обраний Генрі час для нападу був дуже вдалим: Франщію 31407 року роздирала громадянська війна між двома партіями: війна «Арманьяків і Бургіньйонів».

Як помітив бургундський хроніст Жорж Шателен (1405-1475) у «Хроніці мого часу», Генрі «прийшов до Франиії під час поділу $і$ в самий розпал иого, своїм мечем ще більме віддалив один від одного тих, хто $i$ так був розділений»3. Військова справа вимагала від Генрі V колосальних фізичних i розумових навантажень, і хоча він на початку кампаній мав залізне здоров'я (і навіть за свідченням очевидця, носив свої обладунки «як легкий плащу) війна стала початком його кінця4

13 серпня 1415 року англійський флот на чолі 3 Генрі, який розмістився на королівському флагмані «Трініті Роял», увійшов у дельту Сени і біля крейдяного мису Шеф де Ко в Нормандії встав на якір ${ }^{5}$ Після недовгих приготувань, англійська армія розпочала штурм портового міста Арфлер, яке слугувало ключем навігації по Сені, i яке Генрі V хотів використати в якості плащдарму для подальшого методичного завоювання Нормандії та Франції ${ }^{\circ}$ Саме тут ми зустрічаємо перший випадок контакту Генрі і його людей з хворобами. Після 8-ми денной облоги, англійське військо вразила епідемія дизентерії, причому масштаб смертності був настільки великий, що ие закарбували майже всі джерела mієї епохи. В першу чергу потрібно наголосити, що готуючись зі всією ретельністю до кампанії, Генрі розрахував щоденний запас їжі на кожного англійського солдата. Але при дислокації військ і розвантажуванні припасів 3 кораблів більша його частина була зіпсована морською водою7. Також Генрі V розраховував за лічені дні оволодіти Арфлером, втім облога почала затягуватися, тож харчові припаси доводилося економити. Через ие англійuуi мусили їсти

${ }^{3}$ Buchon J. Les chroniques nationalales. Chronique des choses de mon temps par G. Chastellain. Chroniques de J. Lalain /Jehan Buchon. - Paris: Typographie de Ch. Lahure, 1825. - P 18

${ }^{4}$ Съюард Д. Генрих V / Десмонд Съюард. - Смоленск: Русич, 1996. - C.82.

${ }^{5}$ Barker J. Agincourt: Henry V and the Battle That Made England / Juliet Barker. - NewYork: Emeritus fellow of Balliol college Oxford, 2006. - P. 157.

6 Фавъе Ж. Столетняя война / Жан Фавье. - Санкт-Петербург: Евразия, 2017. - С. 336.

7 Бёрн А. Битва при Азенкуре. История Столетней войны с 1369 по 1453 год / Альфред Бёрн - Москва: Центрполиграф, 2004. - С. 34. 
недозрілі і напівгнилі фрукти, які брали з фруктових садів, розташованих на nівнічному заході віd містав. Окрім того, раціон бійців складали місцеві молюски ${ }^{9}$. Вживання зіпсованої їжі англійськими солдатами пояснюється аж ніяк не відсутністю елементарних медичних знань про заходи безпеки. Навпаки, в XV ст., спираючись на гіркий досвід епідемій, люди мали чітке уявлення про шкоду від гнилих або нестиглих фруктів. Так, ще в 1348 році в Пізі, під час епідемії чуми була створена спеціальна комісія, яка слідкувала за якістю товару на ринках ${ }^{10}$. У той же час, італійськими лікарями на чолі з Джентіле да Фоліньо було розроблено спеціальні рекомендації по очищенню організму відносно їжі, пиття, ліків і дезінфекції, хоча в польових умовах вони не виконувалися на практиці11.

Англійська армія стала заручником ситуації і не мала можливості споживати свіжі і якісні харчові припаси, до того ж цьому перешкоджав французький гарнізон Арфлера під командою Рауля де Гокура.

Логічним наслідком споживання уражених хвороботворними мікроорганізмами та їх токсинами продуктів харчування, ще й на фоні різких змін температури, стали харчові інтоксикації. Інтоксикації призвели до серйозних порушень шлунково-кишкового тракту, які згодом через відсутність належного лікування переросли в епідемію дизентерії. Джерела фіксують, що 10-тисячна армія Генрі V почала масово страждати кривавими діареями, які супроводжувалися підвищенням температури тіла, блювотою, слабкістю. Королівський придворний і церковний діяч Джон Капгрейв (1393-1464) у «Хроніці Англії від створення світу до 1417 року» зауважує: «Під час иієё облоги багато людей загинуло від нічних холодів і від того, щзо їли багато (нестиглих - Д. К.) фруктів...»12. Ще один сучасник, бургундський хроніст Ангерран де Монстреле (1390-1453), у «Хроніці» зауважує, що за 8 днів облоги, починаючи з 18 серпня, близько 2000

${ }^{8}$ Перруа Е. Столетняя война / Эдуард Перруа - Санкт-Петербург: Вече, 2002. - С. 254.

${ }^{9}$ Mortimer L. 1415: Henry V`s Year of Glory / Lan Mortimer - London: Vintage, 2009. P. 348.

10 Роулинг М. Европа в Средние века / Марджори Роулинг - Москва: Центрполиграф 2005. - С. 192.

11 Там само.

12 Hingeston C. John Capgrave, The Chronicle of England / Charles Hingeston - London: Longman, Brown, Green, Longmans and Roberts, 1858. - P. 113. 
англійців загинуло від епідемії ${ }^{13}$. Однак відомий своїми неточностями і перебільшеннями Монстреле, ймовірно помиляється у своїх розрахунках. Хворий дизентерією у дуже важкій формі, втративши 20 \% води в організмі помирає приблизно через два тижні. Враховуючи те, що англійці тримали Арфлер в облозі до 22 вересня, померти за такий короткий час від епідеміі така велика кількість людей не могла14.

Хворі солдати вже не могли виконувати своїх функцій, і судячи зі всього, їх намагалися ізолювати від здорових. Перші ознаки епідемії розпочалися з самого прибуття англійських військ. Ймовірно саме через шлункові розлади та їх поширення, Генрі V 3 вересня замовив 600 бочок вина, в якості профілактики кишкових захворювань ${ }^{15}$. Але кисле молоде вино, навпаки погіршило ситуацію. В скорому часі від дизентерії на руках Генрі V помер його вірний слуга і близький друг Куртене Норідж${ }^{16}$. Варто наголосити, що єдиним джерелом інфекції дизентерії є хвора людина, яка небезпечна для оточуючих з 1-го дня хвороби, оскільки виділення збудника в навколишнє середовище в цей період найбільш інтенсивне. На основі цього факту постає логічне питання, як король Генрі, який особисто мав контакт 3 хворим, не заразився ${ }^{17}$. Однак, 3 джерел нам відомо, що королівський табір розташувався на північному заході, приблизно в 1 км. від центру подій, тому можна припустити, що контакти короля 3 важкохворими свідомо прикрашені авторами хронік, щоб підкреслити королівську велич. Протягом всього періоду епідемії, від якої нібито померло 2000 осіб і ще 2000 захворіло, Генрі V на диво залишився здоровим. Це може вказувати на те, що він майже не брав особистої участі в облозі і не підтримував тісного контакту з солдатами. Список хворих за Монстреле складався 32 тис. осіб, серед яких були рідний брат короля - Томас Ланкастер, 1-й герцог Кларенс (1387-1421), (на відміну від старшого брата

13 Renouard J. La chronique d'Enguerran de Monstrelet 1400-1444 / Jules Renouard Paris: Typographie de Ch. Lahure, 1887. - P. 254.

14 Ёлкин И., Крашенинников О. Дизентерия: Эпидемиология и профилактика /Иван Ёлкин, Олег Крашенинников - Москва: Медицина, 1975. - С. 54.

${ }_{15}$ Съюард Д. Генрих V / Десмонд Съюард - Смоленск: Русич, 1996. - С.129, Бёрн А. Битва при Азенкуре. История Столетней войны с 1369 по 1453 год / Альфред Бёрн - Москва, 2004. - С. 35, Cole T. Henry V: The Life of the Warrior King \& the Battle of Agincourt / Teresa Cole - London: Amberley, 2015. - C. 58.

${ }^{16}$ Matusiak J. Henry V / John Matusiak - London: Routledge, 2013, - P. 62.

17 Сегал A. Дизентерия: Популярный очерк /Александр Сегал - Москва: Медицина, 1939. - С. 44. 
Томас мав прямий контакт з хворими) і Роджер Мортімер 5-й граф Марч (1391-1425), i ïx довелося відправити на кораблях в Англію, для лікування. Однак 3 огляду на їх одужання, можна зробити висновок, що хвороба Кларенса і Марча могла бути звичайним харчовим отруєнням, або ж легкою формою дизентерії. Проте і це було смертельно в умовах Середньовіччя, без вживання необхідних заходів. На диво, епідемія дизентерії не вплинула на стан облоги і скоро Арфлер було захоплено. Разом із тим армія Генрі скоротилася на третину.

У 1420 році, після підписання мирного договору в Труа, за яким фактично створювалася нова держава - Об'єднане Королівство Англії $\mathbf{i}$ Франціï, Генрі V був визнаний регентом Франції і спадкоємцем престолу, 3 правом передачі трону своїм дітям. За 12-ю статтею мирної угоди Генрі V потрібно було «якомога швидее схилити до покори або змусити силою коритися (...) непокірні та бунтівні міста, замки і графства...»18. Одним із таких пунктів, було Місто Мо на Марні, розділене рікою з трьох сторін. Французький гарнізон міста здійснював набіги на південні околиці Парижу (який на той час зайняли англійці і їх союзники бургундці). Однак, як нам відомо 3 джерел, напркиінці 1421 року стан Генрі на фоні постійних перевантажень організму і втоми різко погіршився. 3 Англії навіть прибув його особистий лікар, який мусив доглядати за ним в поході на $\mathrm{Mo}^{19}$. Власне цей факт чітко вказує на те, що недуг Генрі був не дизентерією. Ефективних методів лікування дизентерії навіть в пізньому Середньовіччі не було. Тогочасні люди не знали про мікроорганізми (шигелли), які і були збудниками хвороби, тому серйозні шлунково-кишкові хвороби майже завжди мали летальний результат ${ }^{20}$. Смерть від дизентерії наступала через 2-3 і навіть 4 тижні (залежно від форми хвороби) з моменту захворювання. Генрі помер лише 31 серпня 1422 року, себто через рік після того як його здоров'я похитнулося. При цьому, жоден із сучасників (попри заяви окремих хроністів) не описав симптомів дизентерії. Усе це може вказувати на те, що король захворів зовсім іншою хворобою.

Однак смерть Генрі наближалася... Жорж Шателен у своїй праці

${ }_{18}$ Myers A. The treaty of Troyes, 1420. English Historical Documents / Alec Myers London: Published University of Leeds, 1969. - P. 123.

19 Эйрл П. Жизнь и эпоха Генриха V / Питер Эйрл - Санкт-Петербург: Евразия, 2003. - С. 132.

20 Заблудовский П., Крючок Г., Левит М. История медицины /Павел Забулдовский, Григорий Крючок, Михаил Литвин - Москва: Медецина, 1981. - С. 221. 
повідомляє, що в 1421 році Генрі прийняв відлюдника з Фландрії Жана Гентського, який передбачив королю, що «життя його b скорому часі обірветься», здивувавшись, а потім розсміявшись, Генрі не надав цим словам жодного значення ${ }^{21}$. У 1422 році Генрі V, розпочав свою чергову кампанію. Щоб добратися до Мо слід було розчистити долину Йони від військ дофіна Карла, який вважав себе прямим і законним спадкоємцем французького трону 22. Похід на Мо виявився останнім не тільки для значної частини англійської армії, але і для самого англійського короля. Внаслідок постійних бойових дій, частих маршів, недосипань і постійних фізичних навантажень, які постійно відбувалися з 1415 р., у солдатів Генрі знизився імунітет, а на фоні вживання в їжу зіпсованих продуктів через брак провізії спалахнула епідемія дизентерії. За висловом Жана II Жувеналя дез Юрсена (1388-1473) в його «Історії Карла VI короля Франції» англійці піддалися «чудесному покаранню живота - кривавому проносу» і велику кількість «мертвих солдатів знаходили вздовж доріг...»23. Имовірно, що Генрі теж міг заразитися дизентерією яка проходила в легкій формі.

Не дивлячись на хвороби, сам Генрі V мужньо тримався. Звинувачувати його в тому, що він не зробив жодних висновків під час епідемії дизентерії в 1415 році під Арфлером, і в поході на Мо не взяв лікарів, безглуздо. Оскільки кампанія по звільненню долини Йони від дофіністів і похід на Мо вимагала від короля і його армії швидких і рішучих дій, часу на довготривале лікування хворих бракувало. Окрім того, вилікувати людину в польових умовах з дуже важкою формою дизентерії було практично неможливо. Англійська армія із 3 тис. скоротилася до 250024. 6 жовтня, розбивши свій табір в 1 км. від Мо в абатстві Сен-Фаро, Генрі приступив до облоги, але вона затягнулася. Взимку Марна вийшла з берегів і затопила землянки англійських солдатів, а також і приміщення з провізією. До того ж, весь грудень не переставали лити дощі, англійських солдатів

${ }^{21}$ Buchon J. Les chroniques nationalales. Chronique des choses de mon temps par G. Chastellain. Chroniques de J. Lalain /Jehan Buchon. - Paris: Typographie de Ch. Lahure, 1825. - P 156.

22 Басовская Н. Столетняя война. Леопард против лилии / Наталья Басовская Москва: Астрель, 2007. - С. 203.

${ }^{23}$ Pacard, A. Jean Juvénal des Ursins, Histoire de Charles VI, roy de France, et des choses mémorables advenues durant quarante-deux années de son règne: depuis 1380 jusqu'à 1422 / Abraham Pacard - Paris: Avec Privilege du Roy, 1614. - P. 225.

${ }^{24}$ Kingsford C. Henry V / Charles Kingsford - London: Yale University Press, 2017. - 68 p. 
вкотре вразила дизентерія та інші хвороби. До Різдва армія короля скоротилася на 20 \%, однак це не завадило Генрі 10 травня захопити місто після 7 місяців облоги 25 .

Після перемоги під Мо, Генрі відбув у Париж, щоб зустріти з братами свою дружину Катерину де Валуа (1401-1437), яка прибула 3 Англії i привітати ії з народженням сина-спадкоємця ${ }^{26}$. Два дні на початку червня Генрі провів в готелі де Неслі, де переглянув цикл містерій про мучеництво покровителя Англії Святого Георгія, після чого разом 3 Катериною і іï батьками, королем Карлом VI Божевільним (1368-1422) і королевою Ізабеллою Баварською (1370-1435), виїхав в Санліс, де знову сильно захворів. Захворювання було настільки серйозним, що 7 липня 1422 року в Парижі відбулися публічні молитви за його здоров' я27. Можливо дизентерія якою він заразився під Мо почала прогресивно переходити з легкої у важку форму, що зумовило різке погіршення його стану. У серпні армія дофіна несподівано для герцога Бургундії Філіпа III Доброго (1396-1467), взяла в облогу бургундське місто Конс-сюр-Луар. Його капітуляція давала можливість дофіністам через Невір завдати удару по бургундській столиці Діжону. На захист Косна герцог Філіп відправив усі наявні у нього вільні сили, яких виявилось недостатньо, і звернувся до Генрі по допомогу 28 . Той на чолі війська вирушив у Бургундію особисто, однак у Корбеї, що за 80 км від Парижу, йому стало погано. На жаль сучасники не описали симптомів, які супроводжували це, але король змушений був передати командування своєму брату Джону Ланкастеру, 1-му герцогу Бедфорду (1389-1435). Через важкий стан у Корбеї Генрі провів два тижні в ліжку під наглядом свого лікаря, звідки, дізнавшись про перемогу під Косном, вирішив повернутись до Парижу. Лікар порадив йому не одягати обладунків і не сідати на коня, щоб не перевантажувати організм. Прислухавшись до поради, Генрі сів на барку і відбув по Сені до столиці. Стан Генрі настільки покращився, що оминаючи пораду свого лікаря він пересів на коня, однак через декілька метрів втратив свідомість ${ }^{29}$. Тоді було прийнято рішення перевести його

25 Съюард Д. Генрих V / Десмонд Съюард - Смоленск: Русич, 1996. - С.326.

${ }^{26}$ Renouard J. La chronique d'Enguerran de Monstrelet 1400-1444 / J ules Renouard Paris: Typographie de Ch. Lahure, 1887. - P. 332.

27 Hingeston C. John Capgrave, The Chronicle of England / Charles Hingeston London: Longman, Brown, Green, Longmans and Roberts, 1858. - P. 366.

${ }_{28}$ Съюард Д. Генрих V / Десмонд Съюард - Смоленск: Русич, 1996. - Смоленск, 1996. - С.362.

29 Там само. 
знову на барку та доправити до замку Буа-де-Венсен (у резиденцію французьких монархів). Туди його і було доставлено 10 серпня та скеровано його особистого лікаря, а також групу найкращих лікарів Франції. Проблема полягає $b$ тому, що більшість хронік, написаних сучасниками Генрі, майже не відображають симптомів хвороби короля.

Наприклад анонімна хроніка «Брутус Англорум» дає нам скупий матеріал: «...Король переходить з Мо в Брі і 20 серпня прибуває b Париж. I через деякий час король почав відчувати сильні болі... він не міг терпіти цуе» ${ }^{30}$. Згадка про сильні болі, може лише вказувати на серйозне порушення органів людини, але не встановити їх причину.

Ще одне цікаве і нестандартне (порівняно 3 іншими хроніками) повідомлення, міститься в анонімному «Щоденнику паризького городянина»: "Далі, в названий же рік, (1422 p. - Д. К.) в червні і иипні погода видалася вельми і вельми спекотна, і дош, випав не більме одного разу, від чого земля дуже постраждала (...) Внаслідок же настільки великої спеки, у вказаному ж році захворіло безліч дітей, $і$ віспа поширилася настільки, як то не траплялося раніше на ююдській пам'яті. [Хворих же дітей] покривало висипом настільки густим, що неможливо було їх впізнати, і крім того захворіло безліч дорослих, особливо англійиів, подейкували також, ніби сам король англійський заразився вказаною хворобою» 31 . При типовому перебігу віспи інкубаційний період триває 8-14 днів. Початковий період характеризується ознобом, підвищенням температури тіла, сильними болями в попереку, крижах i кінцівках, сильною спрагою, запамороченням, головним болем, блювотою. Іноді початок хвороби м'який. На 2-4-й день на тлі з'являється ініціальний висип або у вигляді ділянок гіперемії, або геморагічне висипання по обидва боки грудної клітини в області грудних м'язів до пахвових западин, а також нижче пупа в області пахових складок і внутрішніх поверхонь стегон. Але окрім сильного болю, сучасники Генрі нічого не повідомляють, і якщу б тіло короля покрилося висипами, ие безсумнівно було б описано хроністами. Окрім того віспа була відома ще $з$ античності, тому, знаючи точний діагноз сучасники не пропонували б свої версії хвороби ${ }^{32}$.

Сучасник Генрі, автор «Першого англійського життя короля Генрі

30 Brie F. The Brut Chronicle or The Chronicles of England / Friedrich Brie - London: Early English Text Society, 1906. - P.429-430.

31 Tuetey A. Journal d'un bourgeois de Paris, 1405-1449 / Alexandre Tuetey - Paris: Typographie de Ch. Lahure, 1881. - P. 350.

32 Смородинцев А. Беседы о вирусах / Александр Смородинцев - Москва: Медицина, 1982. - С. 124. 
П’ятого» Тіто Лівіо Фруловісі (роки діяльності 1430-ті - 1440-ві рр.), дає подібне сухе формулювання: «В дорозі до міста (Парижа - Д. К.) король був охоплений жахливою хворобою, і вимушений був залишитися в місті під назвою Корбей (...) Хвороба короля посилювалася з кожним днем, до тих пір, поки християнський король не відаав свою душу Богу, покинувши це життя в замку, який називається Буа де Венсенн, неподалік від Парижу, де в той час перебував король Карл $i$ дві королеви» 33 . Ще один нечіткий опис міститься в «Бургнудській Хроніці» Жана Лефевра, сеньйора де Сен-Ремі (1395-1468): «Король Англії, котрий перебував у місті Санлісі, погано почував себе... Але, оскільки він почував себе занадто слабким, і йому ставало гірше з кожним днем, він повернувся В Буа де Венсенн, де і скінчилися його дні»з3.

Слабкість і сильні болі скоріше за все в області живота, про що згадують хроністи, є симптомами різних хворіб, у тому числі і дизентерії, ерготизму і виразки. Аналогічний опис смерті подає нам і анонімна «Хроніка Лондона»: «I b останній день названого місяия сериня $b$ тридиять n'ять рокіВ, благороднии Король Генрі $V$, був вимушений покинути християнське мицарство і віддав своє життя в Буа де Сент-Венсенн поблизу Парижа, на велике горе його людей. Нехай помилує його душу Ісус» ${ }^{35}$. Один із небагатьох хроністів, який взагалі називає хвороби короля і їх причини, це монах-бенедиктинець 3 абатства Св. Альбана Томас Волсінгем (помер в 1422 р.). В «Хроніці Майора», він чітко зауважує: «Тим часом король Генрі, який довгий час хворів через свої виснажливі, безперервні праці, був атакований гострою лихоманкою $i$ переважним чином дизентерією, яка настільки розтратила його сили, що його лікарі не наважувалися застосовувати будь-які внутрішні ліки, але були $b$ великому відчаї за його життя. Тому король, розуміючи, що смерть поруч $i$ близька, викликав своїх гериогів та інших, хто міг бути присутнім, і зробив мудрий вибір для королівств Англії та Франції і герцогства Нормандї, склав свій заповіт $і$ вирішив заплатити свої борги зі своїх скарбів $i$ рясних запасів Християнина, він попрощався з изим світом і його людьми, i $b$ істинному покаянні, з вірною і певною вірою $і$ надією, з милосердям до всіх і залишивщи добрі спогади позаду, він віддав свою душу його твориеві 30 серпня, після того як він правив деb'ять років, n'ять місяиів і чотирнадиять днів. Він не залишив собі подібного на

${ }^{33}$ Lethbridge C. Tito Livio Frulovisi The first English life of King Henry the Fifth / Charles Lethbridge - Oxford: The Clarendon Press, 1911. - P. 180-182.

${ }^{34}$ Morand F. Chronique Jean Le Fèvre seigneur de Saint-Remy / François Morand Paris: Typographie de Ch. Lahure, 1876. - P. 60.

${ }^{35}$ Lethbridge C. Chronicles of London / Charles Lethbridge - London:The Claredon Press, 1905. - P. 74. 
землі серед християнських королів або приниів, так щуо не тільки народ Англї $i$ Франиї, але і весь християнський світ оплакували його смерть так, як він изього заслуговував»36. Основний каталізатор хвороби Волсінгем в першу чергу вбачає у військових кампаніях. I він має рацію: кампанії Генрі V окрім бойових дій вимагали від монарха ведення документації, яка через бюрократизм займала багато часу. Окрім того, Генрі встигав займатися реформуванням адміністративного апарату деяких міст в Нормандії, постійно писав листи меру i олдерменам Лондона, в яких описував проведені ним роботи і зроблені досягнення. Постійні суворі, започатковані ним же, військові огляди, особиста участь у битвах, недосипання, фізичні навантаження при переходах, постійні роз'їзди - все це ослабило імунітет. Тому заява Волсінгема про дизентерію виглядає доволі слушною, не може бути, щоб шигелли не потрапили в організм Генрі, коли він при облозі Мо постійно контактував із хворими та особисто вказував цілі для артилерії.

Доволі цікаве повідомлення, всупереч Волсінгему, міститься у «Збірці старих англійських хронік» бургундського хроніста Жана де Вавріна, сеньйора де Форестьє (1400-1474): «Мені було достеменно відомо (...) щуо изе було запалення, яке вразило иого сідниці, яке називалося хворобою Святого Антонія»37. Названа Вавріном хвороба має свою другу назву - ерготизм, причиною було отруєння алкалоїдами (маткові ріжки) жита, які потрапили в борошно iз зернами жита та деяких інших злаків, заражених склероціями. Хвороба Антонія проявлялася у різних формах. Висока доза алкалоїдів викликала у хворого сильне скорочення м'язів без впливу мінімального фізичного навантаження (ходьби і т. д.), що приводило до мученицької смерті. При малих дозах отруєння у хворого були сильні болі в області живота. При найбільш розповсюдженій формі, хвороба Антонія вражала кінцівки; руки i ноги ставали аномально холодними. Симптоми супроводжувалися болісним пекучим болем в уражених кінцівках. Поступово вони чорніли і в кінцевому результаті буквально відвалювалися ${ }^{38}$.

Хліб в середньовіччі, як і зараз, був основою харчування, тому не виключено, що в ході облоги Мо, Генрі V міг споживати уражений ріжками

\footnotetext{
36 Preest D., Clark J. The Chronica Maiora of Thomas Walsingham, 1376-1422 / David Preest, James Clark - London: The Boydell Press, 2005. - P. 445.

37 Jean de Wavrin, Anciennes et nouvelles chroniques dAngleterre [Електронний ресурс]. - Режим доступу до ресурсу: https:/ gallica.bnf.fr/ark:/12148/btv1b10526138x

38 Хаггард Г. От знахаря до врача / Говард Хаггард - Москва: Центрполиграф, 2012 - C. 210.
} 
хліб, який прибував з фуражем річковим шляхом з Парижу. Якщо це дійсно було так, смерть Генрі була неминучою, оскільки єдиний метод лікування «вогню» аж до XVI ст. лежав через паломництво до мощів святого, себто 3 появи хвороби в X ст. не було винайдено жодних ефективних методів боротьби з нею. Лише в 1597 році на медичному факультеті Марбургського університету, після вивчення всіх ймовірних причин захворювання, було встановлено, що хвороба починається після потрапляння в організм ураженого грибком хлібу. У Франщії до цих висновків дійшли лише в 1670 році ${ }^{39}$.

Але досить дивним виглядає швидка смерть Генрі до закінчення гангренозного процесу (якого у Генрі не було), який притаманний вогню святого Антонія. Тому думка Волсінгема більш правдоподібна. Однак, гостра лихоманка і дизентерія цілком могли розвиватись на фоні ерготизму, який прискорив смерть короля. На жаль, сучасні історики, як і їх колеги XX ст., констатуючи факт смерті Генрі V, лише повторюють сухі факти хроністів, не намагаючись дати пояснень і обгрунтувати причини смерті. Так, один з відомих французьких дослідників Столітньої війни Едуард Перруа просто констатує, що хвороба зупинила Генрі разом 3 його завоюванням Франції. Теж саме повторюють і англійські історики Альфред Берн, Марселен Дефурно і Джон Норвіч, а також Айзек Азімов, Вадим Устінов, Наталія Басовська.

I лише Жан Фавьє припустив, що Генрі помер від внутрішньої кровотечі. Пітер Ейрл також зауважив, що: «ніхто точно не знає, чим хворів Генрі. Цілком ймовірно, що це був бич середньовічних воїнів - дизентерія, загострена запаленням внутрішніх органів»40. Найбільш детально останні дні Генрі V дослідив Десмонд $\mathrm{C}^{\prime}$ юард, який висуває декілька версій його смерті, серед яких згадано виразку дванадиятипалої кишки. Сучасні біографи Генрі V, такі як Матусяк, Ліль, Гатчінсон, Коль, Вейл та Кінгсфорд, також подають детальні описи смерті короля, але всі вони засновані лише на розмитих повідомленнях сучасників та ідей C'юарда, і повторюють загальну версію про дизентерію.

Поряд із численними версіями про інфекційні хвороби досить нетиповою є версія камергера Генрі V Пітера Бассета (помер в 1422 р.), який написав «Хроніку короля Генрі П’ятого» (до нашого часу не дійшла). Про

\footnotetext{
39 Там само.

40 Эиррл П. Жизнь и эпоха Генриха V / Питер Эйрл - Санкт-Петербург: Евразия, 2003. - С. 150.
} 
особу Бассета відомо не дуже багато, однак, за свідченням хроніста «Війни Червоної і Білої Троянд» Едварда Голла (1497-1547), в праці «Союз двох благородних і прославлених родин Ланкастерів і Йорків» зауважено, що «Пітер Бассет, котрий під час його (Генрі - Д. К.) смерті був камергером стверджував, щзо він помер від плевриту»41. Небезпека плевриту, полягає у тому, що він починається як застуда, і згодом переходить у важку форму. Починається запалення плевральних пелюсток (оболонок, що оточують легені). Хвороба може протікати по-різному: при ексудативному плевриті між листками плеври накопичується рідина, при сухому - на плевральній поверхні відбувається відкладення білка (фібрину). Зустрічається і гнійний плеврит, при якому у плевральній порожнині (порожнини між пелюстками) накопичується гній. Плеврит часто супроводжує інші хвороби, які на перший погляд не пов'язані з легенями, особливо це спостерігається при наявності пухлин. Однак названа Бассетом основна причина смерті викликає деякі сумніви. Плеврит був відомий людству ще 3 античності: так, римський лікар Клавдій Гален (129/31-200/17) в трактаті «Про сенс для початківців» зауважив: «Я бачив багато ююдей, дорослих $i$ сильних, котрі вилікувалися від плевриту кровопусканням, нерідко самостійно»42. Практичне лікування плевриту було розвинуто і в Середньовіччі, на основі знань накопичених ще в античну епоху, тому навряд чи професійні королівські лікарі не встановили б діагноз і не вилікували б короля. Так само у сучасних британських істориків викликає сумніви посада Бассета: Джоанна Белліс і Лаура Слейтер разом з колегами в книзі «Уявлення війн і насилля 12501600» підкреслили: «На сьогодні день, жоден Пітер Бассет не ідентифікований на особистій службі Генрі $\mathrm{V} »^{43}$.

Після смерті Генрі V Ланкастера 31 серпня 1422 року, народна чутка серед французів приписувала смерть короля божественному втручанню, хоча деякі вважали, що це була проказа. Більшість мешканців однак вважало, що Бог покарав англійського короля за те, щуо той відновив війну у Франиії, яка до нього ніколи не була настільки жорстокою. Витоки цих ідей знайшли своє відображення у «12 книгах про діяння Карла VII і Людовика

${ }^{41}$ Herman P. Hall Edward (1497-1547) / Peter Herman - Oxford: Oxford University Press, 2004. - P. 134.

42 Rede M. Galen: three treatises on the nature of science / Mikhael Rede - Indianapolis: Hackett Publishing Company, 1985. - P. 25

${ }^{43}$ Bellis J, Laura S. Representing War and Violence, 1250-1600 / Joanna Bellis, Slater Laura London: The Boydell Press, 2016. - P. 109. 
XI» французького хроніста Томи Базена (1412-1491). Як єпископ міста Лізьє і типова забобонна людина середньовіччя, причину смерті Генрі V Базен вбачає в «Злі Святого Фіакра», яким Господь покарав його після розграбування англійськими солдатами каплиці Св. Фіакра біля Мо. Базен також повідомляє доволі важливі і цікаві деталі: «у нъого потворно роздувся живіт $і$ ноги» ${ }^{44}$. Хвороба Святого Фіакра відзначається запаленням прямої кишки, а лікування від неї, так само як і від хвороби Святого Антонія практично не було. Таким чином здивовані швидкою смертю молодого монарха, французи серед практично усіх прошарків суспільства утвердили думку про Божу помсту за їх страждання. Навіть наприкінці XV ст. французький історик Філіп де Коммін (1447-1511) в своїх «Мемуарах» розглядав смерть Генрі V як Божу кару, кажучи що: «У них (англійців - Д. К.) тоді був мудрий, вродливий, $і$ дуже хоробрии король Генрі, якому $і$ служили люди навчені і хоробрі... Але, коли Бог відмовив в своїи милості англійцям, цей мудрий король помер у Венсеннському лісі...»45.

Як би там не було, рятувати короля було вже пізно. Генрі, який пролежав в своєму ліжку у Венсенні до кінця серпня 1422 року, почував себе 3 кожним днем гірше і гірше, став блідим та не міг приймати їжу. Останні його дні більш детально описали хроністи Фруловісі, Лефевр і Монстреле. Останній повідомляє: "Тоді Генрі, знаючи, що він страждає від смертельної хвороби, відправив за своїм братом гериогом Бедфордом, свого дядька графа Воріка, сера Льюіса Робсарта і трьох або чотирьох інших, котрим Він більш за Все довіряв, зі всіх тих, хто був при ньому, і сказав їм з жалобою, що він знав, що ие була воля його твория, що він має покинути цей світ (...) Незабаром після цього, король послав за своїми лікарями і наполегливо попросив їх розказати иому, що вони думають про його стан і як довго він може прожити. Вони коливалися, перш ніж відповісти, а після, щоб дати йому надію сказали йому, що від Бога залежить, чи буде відновлено його здоров'я. Він не був задоволений ијєю відповіддю $i$ знову попросив сказати йому правду. Потім, лікарі обговорили це питання між собою, $i$ потім один із них, стоячи на колінах біля королівського ліжка, сказав иому: «Мій лорд, подумайте про вашу душу. Все в руках Господа, але ми вважаємо, шо вам залишилося не більще двох годин» ${ }^{46}$. Генрі закликав свого духівника, 3 яким

44 Spencer M. Thomas Basin (1412-1490): The History of Charles VII and Louis XI / Mark Spencer - Nieuwkoop: De Graaf Publishers, 1997. - P 78

45 Филипn де Коммин. Мемуары / Перевод, статья и примечания Ю. П. Малинина - Москва: Наука. 1986. - С. 16.

46 Renouard J. La chronique d'Enguerran de Monstrelet 1400-1444 / J ules Renouard Paris: Typographie de Ch. Lahure, 1887. - P. 357. 
вони прочитали сім покаянних псалмів і літургію латиною. Він отримав святе причастя і був помазаний. Наприкінці ритуалу залізна самовпевненість зрадила йому і на мить Генрі злякався за свою душу й несподівано вигукнув, немов у відповідь якомусь злому духові: «Ти брешеш, ти брешеш, моя доля бути з Господом Ісусом Христом!»47. Біля півночі 31 серпня 1422 року, коли відпущені лікарями години минули, серце Генрі V Ланкастера перестало битися. Иого останніми словами були: «in manus tuas, Domine, ipsum terminum redemisti»48. Персіваль де Каньї, хроніст Жана II Доброго, герцога Алансонського (1409-1476), додає: «Багато хто з його супротивників, фрраниузів, і з тих, хто тримав иоого сторону, говорили (...), щзо, якби він залишився живим $і$ зі здоровим розумом, він би завоював все королівство» ${ }^{49}$.

Підсумовуючи, треба зауважити, що лише повідомлення Волсінгема, Базена, Вавріна і Бассета схоже є правдивими, однак більш переконливий опис клінічної картини містить саме оповідь Базена. У Генрі не затримувалася їжа в шлунку і потворно здулись живіт та ноги. Якщо Генрі дійсно заразився дизентерією, як пише Волсінгем, то на ії фоні потворно здутий живіт та ноги можуть бути поясненими розвитком вкрай рідкісного ускладнення у вигляді міокардиту - інфекційного запального ураження серцевого м'язу. Але він не був діагностований i, поступово, через постійні перевантаження в походах і військових діях, можливо почала розвиватися декомпенсація серцевої діяльності. Усе це вилилося у середню недостатність, яка проявилася наростаючою слабкістю, набряками нижніх кінцівок, випотом в черевну і плевральну порожнини. Слабкість ураженого запальним процесом міокардиту і прогресування серцевої недостатності призвело до смерті короля. Міокардит часто розвивається на фоні інфекційних захворювань, таких як дизентерія, хоча можливо й те, що він розвинувся при отруєнні алкалоїдами, про що свідчить Ваврін. Брак описів лікарів лише змушує здогадуватися про справжні симптоми. По смерті Генрі його нутрощі були поховані в церкві Сен-Мор-де-Фосс в Венсенні, а розрізане на частини тіло виварили у вині, після чого забальзамовану в

47. Lethbridge C. Tito Livio Frulovisi The first English life of King Henry the Fifth / Charles Lethbridge - Oxford: The Clarendon Press, 1911. - P. 190.

48 Переклад з лат.: «В твої руки, Господи, в самий останній момент віддаю себе».

49 Leslie G. Henry V. The Practice of Kingship / Gerald Leslie - Oxford: Oxford University Pres, 1985. - P. 67. 
спеціях плоть і кістки помістили в свинцеву труну ${ }^{50}$.

В Англію рештки Генрі прибули лише 5 листопада 1422 р. i, після пишних церемоній прощання 3 королем, не притаманних навіть епосі Середньовіччя, його поховали у Вестмінстерському абатстві. За відсутністю описів хвороби лікарями Генрі, історія його хвороби залишається, не дивлячись на припущення, білою плямою в історії середньовічної медицини. Зі смертю Генрі V Ланкастера, а через шість тижнів - його тестя, Карла VI, було порушено порядок престолонаслідування, закріплений договором в Труа.

Скориставшись тим, що Франція опинилася без правителя, i наступного ж дня по смерті батька, 22 жовтня 1422 року, його син, дофін Карл, оголосив себе королем в Пуатьє і у 1429 році коронувався в Реймсі як Карл VII. Через два роки по цьому, у Парижі на французький престол під іменем Генрі II коронувався і 10-річний Генрі VI Ланкастер. Війна між двома королями Франції тривала до 1453 року й закінчилась поразкою Англії, яка на континенті втратила всі володіння, окрім Кале у Пікардії.

MA in History Dmytro Kopylov (Lviv, Ukraine)

Sickness and Death of a Ruler of the State: The Case of Henry V of Lancaster

The article provides a detailed analysis and description of the disease of the king of England, Henry V of Lancaster, based on little-known sources. In particular, littleknown episodes of the last days of the English monarch are covered, the historical and legal characteristics of the course of the disease are provided, the political and legal consequences of his death for the idea of creating the United Kingdom of England and France are substantiated.

Keywords: Henry V of Lancaster, the Hundred Years War, the United Kingdom of England and France, Dysentery, Fever, Fire of St. Anthony, Evil of St. Fiacre, Pleurisy, Myocarditis.

магистр Дмитрий Копылов (Львов, Украина)

Болезнь и смерть правителя государства: случай Генри V Ланкастера

В статье проводится детальный анализ и описание заболевания короля Англии

50 Ця процедура виникла скоріш за все під час Хрестових походів, коли тіла аристократів-хрестоносців виварювали в окропі щоб відділити плоть від кісток і відправляли останки на батьківщину. Виварення частин тіла в окропі мало одну мету - не допустити процес гниття тіла під час транспортування на велику відстань. В 1300 р., з цієї нагоди, папа Боніфацій спеціальним наказом заборонив проведення таких процедур, але на практиці його заборони майже не дотримувалися. 
Генри V Ланкастера на основе малоизвестных сообщений источников. В частности, освещены малоизвестные эпизоды последних дней английского монарха, предоставлена историко-правовая характеристика протекания болезни, обоснованны политико-юридические последствия его смерти для идеи создания Объединенного Королевства Англии и Франции.

Ключевые слова: Генри V Ланкастер, Столетняя война, Объединённое Королевство Англии и Франции, дизентерия, лихорадка, «огонь святого Антония», «зло святого Фиакра», плеврит, миокардит.

магістр Дмитро Копилов (Львів, Україна)

Хвороба і смерть правителя держави: випадок Генрі V Ланкастера

У статті проведено детальний аналіз і опис захворювання короля Англії Генрі V Ланкастера на основі маловідомих джерельних даних. Зокрема, висвітлено епізоди останніх днів англійського монарха, надано історико-правову характеристику перебігу хвороби, обгрунтовано наслідки його смерті для ідеї створення Об'єднаного Королівства Англії і Франції.

Ключові слова: Генрі V Ланкастер, Столітня війна, Об'єднане Королівство Англії і Франції, дизентерія, лихоманка, «вогонь святого Антонія», «зло святого Фіакра», плеврит, міокардит.

* Копилов Дмитро Олексійович - магістр історії історичного факультету Львівського національного університету імені Івана Франка.

E-mail: vlad.kiorsak@gmail.com. 